\title{
Improving Complementarity Effect of Legume Intercrop by Earthworm Facilitation for Wheat Performance
}

\author{
Baptiste Drut ${ }^{1}$, Nathalie Cassagne ${ }^{1}$, Mario Cannavacciuolo ${ }^{1}$, Gaëtan Le Floch ${ }^{2}$, \\ José F. Cobo-Díaz ${ }^{2} \&$ Joëlle Fustec ${ }^{1}$ \\ ${ }^{1}$ USC 1432 LEVA, Ecole Supérieure d'Agricultures (ESA), INRA, SFR 4207 QUASAV, Angers, France \\ ${ }^{2}$ EA 3882 LUBEM, ESIAB Technopôle de Brest-Iroise, Plouzané, France \\ Correspondence: Joëlle Fustec, USC 1432 LEVA, INRA-ESA, 55 rue Rabelais, BP 30748, 49007 Angers cedex \\ 01, France. Tel: 33-241-235-555. E-mail: j.fustec@groupe-esa.com
}

Received: July 27, $2018 \quad$ Accepted: September 9, $2018 \quad$ Online Published: November 15, 2018

doi:10.5539/jas.v10n12p1 URL: https://doi.org/10.5539/jas.v10n12p1

The research was financed by the Regions Pays-de-la-Loire and Bretagne (France) as part of the project SAFARI.

\begin{abstract}
Intercrops and crop mixtures are considered to be a way to increase nitrogen use efficiency by promoting niche complementarity and facilitation, reducing the input of fertilizers and herbicides, which are important factors when considering the effects of climate change. However, interactions between crop communities and soil functional diversity also have major effects on crop cover function. Our study aimed to investigate the simultaneous effects of plant composition and presence of earthworms on the growth (roots and shoots) of wheat (Triticum aestivum L.). Mesocosms filled with soil were sown with either 6 wheat plants of the same cultivar, or 6 plants of 3 different wheat cultivars, or 3 wheat plants of 3 different cultivars with 3 clover plants (Trifolium hybridum L.). A part of the mesocosms was inoculated with either endogeic earthworms (Aporrectodea caliginosa S.) or a mixture of endogeic and anecic earthworms (Lumbricus terrestris S.). A relative interaction index was calculated to highlight competition strength between plants with or without earthworms. The presence of different cultivars had no influence on wheat performance, but with clover, plant competition decreased to the benefit of wheat biomass and $\mathrm{N}$ accumulation. Earthworms also reduced the competitive strength between wheat plants in mixed-cultivar mesocosms and in intercropping. In intercrops with clover, wheat performance was improved as a result of niche complementarity and earthworm facilitation for $\mathrm{N}$ resource. Our results suggest that the plant functional group, such as legumes, and earthworm communities work synergistically to improve wheat yields.
\end{abstract}

Keywords: earthworms, functional diversity, intercropping, legumes, niche separation

\section{Introduction}

\subsection{Intercrops for Sustainable Cropping Systems}

The wide-spread use of chemical fertilizers has led to a dramatic increase in reactive nitrogen $(\mathrm{N})$ levels in the biosphere (Galloway et al., 2003), with negative consequences on water quality, human health, biodiversity and climate change. Growing legumes is an effective way to integrate atmospheric $\mathrm{N}$ into cropping systems and thus increase soil fertility and reduce mineral $\mathrm{N}$ fertilizer input and the use of associated fossil fuels. As defined by Willey (1979), intercropping consists of simultaneously growing two or more crop species in the same field for a significant period of time. Intercropping with a legume is often considered an effective way to combine improvements in crop productivity and economic performance with a low environmental impact (Pelzer et al., 2012). Recent studies have shown that intercrop performance is mainly based on complementarity related to light, water and nutrients and on positive biotic interactions (Hauggaard-Nielsen et al., 2009; Brooker et al., 2016; Bédoussac et al., 2015; Neugschwandtner \& Kaul, 2015; Gaba et al., 2015; Duchene et al., 2017). Thus, in cases of low mineral $\mathrm{N}$ availability, intercropped legumes influence the $\mathrm{N}$ supply for non- $\mathrm{N}$-fixing companion species by reducing competition between functional groups (Corre-Hellou et al., 2006). Mixtures of different cultivars are also often considered to be effective plant cover options to face the new challenges of climate change and 
crop sustainability (S. J. Sarandon \& R. Sarandon, 1995; Fang et al., 2014). However, niche separation among plants of the same community is not the only process thought to have a positive effect on crop nutrition and yields. Complex plant(s)-soil interactions also play a major role in crop cover performance, with consequences on the management of trade-offs within crop cover leading to improved productivity.

\subsection{Effect of Crop Composition on Plant-Soil Interactions}

Legumes are known to produce residues and N-rich rhizodeposits (Fustec et al., 2010) that benefit earthworms (Kreuzer et al., 2004), which increase the decomposition of plant residues and soil $\mathrm{N}$ availability to other plants. This mediation of the role of legumes by decomposers may also reduce competition between plants (Eisenhauer, 2012). In addition, plant diversity and composition induce changes in the structure of microbial communities within rhizospheric soil (Kowalchuk et al., 2002; Laughlin et al., 2010). The selective effect of plants linked to the specific composition of their exudates, and more broadly rhizodeposition, shapes microbial diversity within the rhizosphere (Dennis et al., 2010; Zancarini et al., 2012; Bobille et al., 2016; Taschen et al., 2017). It can be assumed that greater plant diversity may lead to greater heterogeneity in the type of exudates, with the ability to harbour a higher diversity of microorganisms. Kowalchuk et al. (2002) showed that when plant diversity is low, microbial diversity is generally lower in the rhizosphere than in non-rhizospheric soil. Plants feed on minerals supplied by microorganisms, and the latter use those provided by the plants, notably carbon (C)-containing minerals. As a consequence, $\mathrm{C}$ fluxes modify microbial activity and probably the balance between mineralization and the immobilization of nutrients (especially $\mathrm{N}$ ) in the rhizosphere (Paterson et al., 2005). This highlights the interdependence of $\mathrm{C}$ and $\mathrm{N}$ dynamics at the plant-soil interface. Plants are able to actively influence these processes depending on their traits; for instance, the presence of N-fixing nodules (Zhu \& Cheng, 2012), foliar biomass (Dijkstra et al., 2006) or the molecular weight of exudates (Balesdent et al., 2011) can significantly affect these dynamics. $\mathrm{N}$ rhizodeposition enhances niche separation for $\mathrm{N}$ use within the rhizosphere between plants having a higher affinity for mineral $\mathrm{N}$ and microorganisms that preferentially consume organic $\mathrm{N}$ from exudates (Kuzyakov \& Xu, 2013).

\subsection{Effect of Earthworms on the Plants}

Earthworms, because of their burrowing activity and soil ingestion, are identified as ecosystem engineers and strongly influence soil structure and properties (Curry \& Schmidt, 2007; Lavelle \& Spain, 2001). At the same time, by changing the distribution and availability of nutrients and the activity and composition of the bacterial community, earthworms indirectly influence the composition and growth of plant communities (Eisenhauer $\&$ Scheu, 2008; Laossi et al., 2009; van Groenigen et al., 2014; Brolsma et al. 2017; Mudrák \& Frouz, 2018). The activity of earthworms creates conditions favourable for the activation of specific bacteria by bringing them into contact with soil organic matter (SOM), enhancing its decomposition (Bernard et al., 2012). Several published studies also report a significant change in the biomass and root architecture of plants in the presence of earthworms (Puga-Freitas et al., 2012; Coulis et al., 2014) caused, for example, by $\mathrm{NH}_{4}{ }^{+}$excretion by some earthworms (Gomez-Brandon et al., 2010), the stimulation of $\mathrm{N}$ mineralization (Bityutskii et al., 2012a), and greater solubility of micro-elements such as zinc, iron and manganese in worm castings (observed in Aporrectodea caliginosa; Bityutskii et al., 2012b).

However, contradictory results have also been reported (Scheu, 2003; Kreuzer et al., 2004) with positive, negative or no-significant effects of earthworms depending on the functional groups of the plants involved. Therefore, this can influence plant interactions in intercropped species. Earthworms can alter root growth and architecture, with differences among plant species and varieties that influence competitive strengths for water and $\mathrm{N}$ within the plant cover (Wurst et al., 2005; Eisenhauer \& Scheu, 2008).

The objectives of this study were to assess and compare the effect of plant composition (pure wheat, mixture of wheat cultivars, wheat intercropped with a legume), the effect of earthworms, and the coupled effect between the plant cover and the worms (1) on the biomass and $\mathrm{N}$ accumulation of wheat, and (2) on soil bacterial communities.

\section{Materials and Methods}

\subsection{Experimental Design}

An experiment was carried out in a greenhouse (Angers, France, 47 $28^{\prime} 0^{\prime \prime} \mathrm{N}, 0^{\circ} 47^{\prime} 31^{\prime \prime} \mathrm{W}$ ) from March to June 2015 (temperatures night/day: $14.0 \pm 2.8^{\circ} \mathrm{C} / 25.2 \pm 4.7{ }^{\circ} \mathrm{C}$ ). Plants were grown in mesocosms (6 plants per mesocosm) that consisted of PVC tubes (diameter $20 \mathrm{~cm}$, height $45 \mathrm{~cm}$ ) fixed on a perforated stainless-steel base (Figure 1). The mesocosms were filled with $12.5 \mathrm{~kg}$ of dry soil sieved at $7 \mathrm{~mm}$. The soil was collected from a field previously cropped as grassland at an organic farm $\left(47^{\circ} 36^{\prime} 57.5^{\prime \prime} \mathrm{N}, 0^{\circ} 39^{\prime} 47.4^{\prime \prime} \mathrm{W}\right)$. The soil was a sandy 
loam consisting of $36.2 \%$ coarse sand, $12.0 \%$ fine sand, $19.6 \%$ coarse silt, $19.6 \%$ fine silt, $10.0 \%$ clay, $2.6 \%$ organic matter, with the following properties: $\mathrm{pH} 6.4,1.41 \% \mathrm{C}, 0.14 \% \mathrm{~N}, \mathrm{C}: \mathrm{N} 9.1$, P Olsen $87 \mathrm{mg} \mathrm{kg}^{-1}, \mathrm{~K}^{174}$ $\mathrm{mg} \mathrm{kg}{ }^{-1}, \mathrm{Mg} 78 \mathrm{mg} \mathrm{kg}^{-1}, \mathrm{NO}_{3}^{-} 20.52 \mathrm{mg} \mathrm{kg}^{-1}, \mathrm{NH}_{4}{ }^{+} 2.65 \mathrm{mg} \mathrm{kg}^{-1}$.

The mesocosms were arranged on culture tables according to a randomized complete block design with five replicates of each treatment group. Each mesocosm was sown with 6 plants of either 6 wheats of the same cultivar (Triticum aestivum L.cv Renan; W), or 6 wheats of 3 different wheat cultivars (T. aestivum L. cv Renan, Chevalier \& Pireneo; MW), or wheats of 3 different cultivars with 3 clover plants (Trifolium hybridum L. cv Aurora; MWC). Within each type of plant cover, mesocosms were or were not inoculated with either five endogeic earthworms (Aporrectodea caliginosa S.) or five endogeic and two anecic earthworms (Lumbricus terrestris $\mathrm{S}$.). The number of earthworms per mesocosm was chosen for consistency with the abundance found in French arable soils (Ponge et al., 2013), corresponding to the equivalent of 63.7 ind $\mathrm{m}^{-2}$ for anecic and 158.5 ind $\mathrm{m}^{-2}$ for endogeic earthworms. The mean biomass of earthworms added to the mesocosms was $3.2 \pm 0.5 \mathrm{~g}$ for treatments with five endogeic individuals and $3.3 \pm 0.5 \mathrm{~g}$ (endogeic) and $6 \pm 0.7 \mathrm{~g}$ (anecic) for treatments in which the two functional groups were mixed. Controls without plants (NP) and either without earthworms, or with endogeic, or with endogeic and anecic earthworms were also included in the experiment. Pre-germinated seeds (at $20^{\circ} \mathrm{C}$ ) were sown in the mesocosms. For each wheat plant, two seeds were planted, and three for clover. Seedlings were selected at 8 and 19 days after sowing for wheat and clover, respectively. To feed anecic earthworms, $1 \mathrm{~g}$ autoclaved dried grass was added on the top of the soil each fortnight (Lee, 1985). Mesocosms were watered twice a week to maintain $20 \%$ water content.

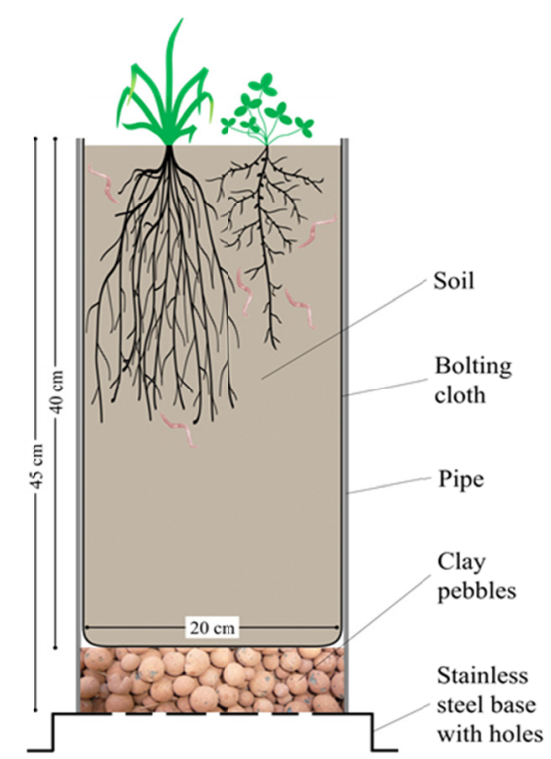

Figure 1. Experimental mesocosm system

Note. 1-cm diameter holes in the base and clay pebbles promote soil drainage and aeration. The soil was contained in a bag of bolting cloth $(25 \mu \mathrm{m}$ mesh) to allow the harvest of the entire root system and all earthworms at the end of the experiment.

\subsection{Sampling and Measurements}

At 117 days after sowing (DAS), plants covered 100\% of the mesocosm surface. Plant shoots were sampled and pooled per species and cultivar. At this stage, $60 \%$ of the wheats were at tillering, $30.7 \%$ at stem extention, $0.4 \%$ at heading and $8.9 \%$ at flowering. For each mesocosm, the aboveground parts of plants were clipped at the base of the stem and pooled per species and cultivar before drying at $70^{\circ} \mathrm{C}$ for $48 \mathrm{~h}$. The entire area of the mesocosms colonized by roots was collected, and the roots were gently extracted from the soil. In $\mathrm{W}$ and MW, roots were pooled into single samples. In MWC, three distinct samples were collected: $i$ ) clover roots, $i i$ ) wheat roots, and iii) unidentified roots. Roots were then rinsed with water to remove adhering soil particles and oven-dried at $70{ }^{\circ} \mathrm{C}$ for 48 hours. All plant samples were weighted, ground into a fine powder and prepared for $\% \mathrm{~N}$ and ${ }^{15} \mathrm{~N}:{ }^{14} \mathrm{~N}$ analyses using a mass spectrometer (IsoPrime, Elementar; Hanau, Germany) coupled to an elemental analyser (EA3000, Euro Vector; Milan, Italy). 
The soil from each mesocosm was sieved at $2 \mathrm{~mm}$. One part was weighed before and after drying at $70{ }^{\circ} \mathrm{C}$ during $48 \mathrm{~h}$ for determining the water content. A sample $(>1 \mathrm{~g})$ was stored at $-80{ }^{\circ} \mathrm{C}$ for microbial analyses. Recovered earthworms were washed and weighed.

\subsection{Bacterial Biomass and Communities}

Microbial DNA was extracted from $1 \mathrm{~g}$ of fresh soil using a NucleoSpin ${ }^{\circledR}$ Kit (Macherey-Nagel GmbH \& Co. KG; manufacturer's instructions). The DNA extracts were re-suspended in $60 \mu \mathrm{L}$ ES buffer $(5 \mathrm{mM}$ Tris/ $\mathrm{HCl}, \mathrm{pH}$ 8.5). The quality and concentration of purified DNA were determined using a UV spectrophotometer (NanoDrop 1000, Thermo Scientific, USA), and dilutions of at least $10 \mathrm{ng}^{-1}{ }^{-1}$ were prepared for each DNA sample.

Bacterial biomass was assessed using a real time polymerase chain reaction (PCR) assay targeting 16S rRNA using the following bacteria-specific primers: NADF (5'-TCCTACGGGAGGCAGCAGT-3') and NADR (5'-GGACTACCAGGGTATCTAATCCTGTT-3') (Nadkarni et al., 2002). The amounts of bacterial DNA in samples were measured separately via fluorescence using an external standard curve generated from serial dilutions of bacterial DNA from a pure culture (Escherichia coli). Each PCR mixture contained $10 \mu \mathrm{L}$ of Supermix Sso FastTM Eva Green ${ }^{\circledR}$ (CBiotium, Inc.), $1 \mu \mathrm{L}$ of each forward and reverse primers, and $1 \mu \mathrm{L}$ of DNA and was brought to $25 \mu \mathrm{L}$ with sterile deionized water. After denaturation at $98{ }^{\circ} \mathrm{C}$ for 2 minutes, the PCR products were amplified for 40 cycles at $98{ }^{\circ} \mathrm{C}$ for 30 seconds and $60{ }^{\circ} \mathrm{C}$ for 30 seconds. PCR amplification efficiency was established based on calibration curves, with a minimum of $85 \%$.

A total of 48 samples were selected for amplicon PCRs and Illumina Miseq PE300 sequencing, which was performed at the McGill University and Genome Quebec Innovation Centre; Montréal, Canada. Paired reads were processed with QIIME (Quantitative Insights Into Microbial Ecology) (Caporaso et al., 2010) using the multiple_join_paired_ends.py and multiple_split_libraries_fastq.py scripts with default parameters. The chimeric sequences were identified and removed using the UCHIME algorithm (Edgar et al., 2011) with vsearch v1.1.3 (https://github.com/torognes/vsearch) and the ChimeraSlayer reference database (Haas et al., 2011). The UCLUST algorithm (Edgar, 2010) was used for choosing OTUs. To minimize the inflation of rare OTUs in the community analysis, we included only OTUs with a sequence count greater than 10 (Brown et al., 2015; Oliver et al., 2015). Additionally, OTUs from chloroplasts and mitochondria and those "Not assigned" were discarded. A single rarefaction with 30485 sequences per sample was created for alpha-diversity analysis (which excluded replicates MW5, MWC2 and W4, with 12 706, 14288 and 18155 sequences, respectively).

\subsection{Calculations and Statistics}

\subsubsection{Root Biomass in the Mixtures}

Assuming that the stable $\mathrm{N}$ isotope signature of a species mixture reflects the isotope signatures of the component species and their proportions in the mixture, differences in natural ${ }^{15} \mathrm{~N}$ abundance were used to distinguish root biomasses of clover and wheat in the sample of unidentified roots in the MWC (Corre-Hellou and Crozat, 2005). The mass of ${ }^{15} \mathrm{~N}$ in the mixture of roots from different species $\left(\mathrm{Q}^{15} \mathrm{~N}_{\mathrm{MWC}}\right)$ is the sum of the products of natural ${ }^{15} \mathrm{~N}$ abundance $\left(\delta^{15} \mathrm{~N}\right)$ and root $\mathrm{N}$ (Root $\left.\mathrm{DW} \times \% \mathrm{~N}\right)$ of the component species (Equation 1).

$$
\begin{aligned}
Q^{15} N_{M W C} & =\operatorname{Root} D W_{M W C} \times \% N_{M W C} \times \delta^{15} N_{M W C} \\
& =\left(\operatorname{Root} D W_{C} \times \% N_{C} \times \delta^{15} N_{C}\right)+\left(\operatorname{Root} D W_{W} \times \% N_{W} \times \delta^{15} N_{W}\right)
\end{aligned}
$$

Root $\mathrm{DW}_{\mathrm{MWC}}$, Root $\mathrm{DW}_{\mathrm{C}}$, Root $\mathrm{DW}_{\mathrm{W}}$ are the root dry weights of the mixture, clover and wheat, respectively. $\% \mathrm{~N}_{\mathrm{C}}$ and $\% \mathrm{~N}_{\mathrm{W}}$ correspond to the percentage of $\mathrm{N}$ in the roots of clover and wheat, respectively. Therefore, the contribution of each species to the root biomass of the mixture was calculated from Equations 2 and 3 as follows:

$$
\begin{gathered}
\% \text { Root } D W_{C}=\left[\left(\% N_{M W C} \times \delta \%{ }^{15} N_{M W C}\right)-\left(\% N_{W} \times \delta \% N_{W}\right)\right] /\left[\left(\% N_{C} \times \delta \%{ }^{15} N_{C}\right)-\left(\% N_{W} \times \delta \% N_{W}\right)\right] \\
\% \text { Root } D W_{W}=100-\% \text { Root DW } W_{C}
\end{gathered}
$$

\subsubsection{Biological N Fixation (BNF)}

The rate of $\mathrm{N}$ derived from BNF (\%Ndfa) in the clover was calculated based on the natural abundance of ${ }^{15} \mathrm{~N}$ in clover grown in mesocosms (Shearer and Kohl, 1986). The \%Ndfa was calculated by using Equation 4:

$$
\% N d f a=\left[\left(\delta^{15} N_{\text {Renan }}-\delta^{15} N_{C}\right) /\left(\delta^{15} N_{\text {Renan }}-\beta\right)\right] \times 100
$$

where, $\delta^{15} \mathrm{~N}_{\text {Renan }}$ and $\delta^{15} \mathrm{~N}_{\mathrm{C}}$ are the parts per 1000 of ${ }^{15} \mathrm{~N}$ enrichment of $\mathrm{N}$ in the Renan cultivar grown in the single-wheat cultivar treatment group and in the treatment group with clover grown in a mixture of three cultivars of wheat intercropped with clover plants with or without earthworms, respectively. $\beta$ is a measure of isotopic fractionation during BNF, which was determined from the $\delta^{15} \mathrm{~N}(\%)$ of the aboveground parts of clovers 
grown in the same greenhouse in pure sand and watered with an N-free diluted nutrient solution $(\mathrm{n}=5)$. Those clover plants were sown and harvested at the same time as the plants in the mesocosms.

\subsubsection{Interaction Index}

A relative interaction index was calculated to highlight competition strength between plants with or without earthworms. We used the relative interaction index (RII) to compare the relative importance of inter- versus intragenotypic competition in the case of the wheat cultivar mixture. The RII was calculated using Equation 5 below as adapted from Armas et al. (2004).

$$
R I I=\left(D W_{\text {Renan_ }} M W-D W_{\text {Renan_}} W\right) /\left(D W_{\text {Renan__ }} M W+D W_{\text {Renan }}\right)
$$

where, $\mathrm{DW}_{\text {Renan_}} \mathrm{W}$ is the mean biomass of a Renan wheat plant grown in pure stand, and DW $\mathrm{Renan}_{\mathrm{B}} \mathrm{MW}$ is the biomass of one plant of the Renan wheat cultivar grown in a mixture of cultivars. In the case of the wheat-clover intercrops, the RII compares the relative importance of inter- versus intraspecific competition. In this case, RII was calculated using equation 6 from Armas et al. (2004):

$$
R I I=\left(D W_{\text {Renan_}} M W C-D W_{\text {Renan_ }} M W\right) /\left(D W_{\text {Renan_ }} M W C+D W_{\text {Renan_ }} M W\right)
$$

where, $\mathrm{DW}_{\text {Renan_}} \mathrm{MW}$ is the mean biomass of one plant of wheat grown in the mixture of wheat cultivars, and $\mathrm{DW}_{\text {Renan_}} \mathrm{MWC}$ is the biomass of one plant of wheat grown in the clover-wheat intercrop.

RII values range from between -1 and 1 . Negative values correspond to competition where intergenotypic or interspecific competition is higher than intragenotypic or intraspecific competition. Positive values correspond to complementarity and/or positive interactions where intergenotypic or interspecific competition is lower than intragenotypic or intraspecific competition. RII was calculated for wheat biomass production and $\mathrm{N}$ accumulation with or without earthworms.

\subsection{Statistical Analysis}

Two-way analyses of variance that considered crop $\times$ earthworm treatments were performed on the biomass and $\mathrm{N}$ concentration of plants on bacterial biomass and indices of community structure. Data were log-transformed before analyses to meet the assumption of the test. Significant differences between means were determined using Tukey's multiple comparison tests at a 0.05 probability level. R software (version 3.1.1.) was used for statistical analyses (R Core Team, 2014). Student's t-tests were used to evaluate whether a value of RII was significantly different from 0, i.e., null interaction. The effect of earthworms on RII values was tested using a one-way analysis of variance (ANOVA) with earthworm treatment as a factor at a probability level of 0.05 .

A total of 2211523 sequences of 16S rRNA genes were clustered into 11095 OTUs after filtering raw reads from 48 soil samples (4 plant treatments $\times 3$ earthworm treatments $\times 4$ replicates). Between 12706 and 57529 sequences per sample were obtained, and 30485 sequences per sample were extracted for diversity analysis, excluding three samples with less than 18000 sequences each.

\section{Results}

\subsection{Plant Growth, N Use and Effect of Earthworms}

The plant composition and the presence of earthworms significantly affected root and shoot wheat DW ( $p<$ 0.001 , Figure 2A, Table A1). A significant effect of the earthworms was observed, with an increase of $26 \%$ in shoot DW for W and MW, and a 34\% increase in root DW for MW. Endogeic earthworms significantly increased wheat shoot DW by $11 \%$ for MW. For MWC, wheat shoot DW was two-fold higher than W and MW. For MWC, earthworms respectively increased wheat root and shoot DW by $50 \%$ and $20 \%$, respectively. 

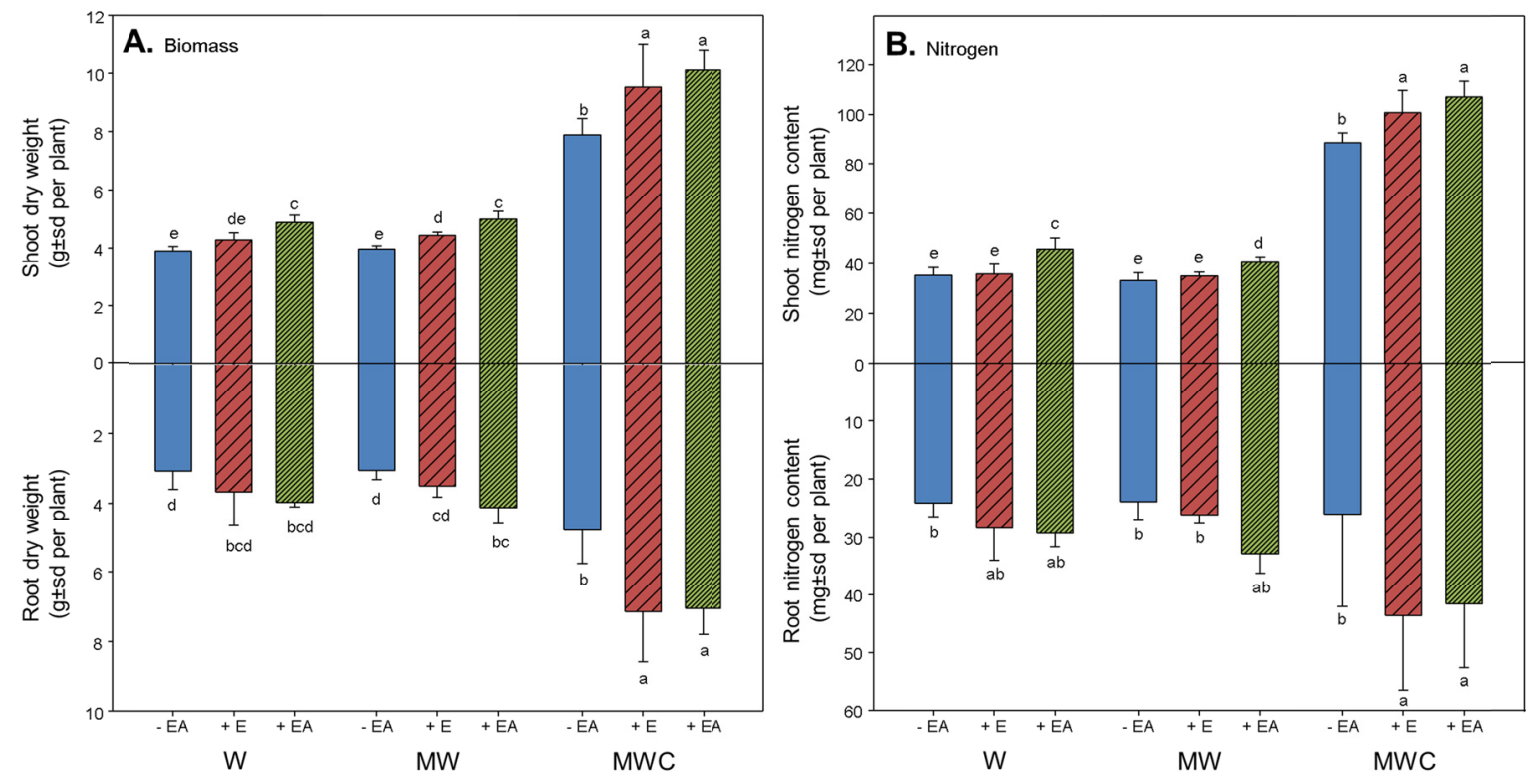

Figure 2. Dry weight (A) and nitrogen content (B) of wheat shoots and roots in different plant cover types and earthworms treatments

Note. $\mathrm{W}=$ single cultivar, $\mathrm{MW}=$ mixture of three cultivars, $\mathrm{MWC}=$ mixture of cultivars intercropped with clover, $-\mathrm{EA}=$ without earthworms, $+\mathrm{E}=$ with endogeic, $+\mathrm{EA}=$ with endogeic and anecic. Values are the means of 5 replicates. Bars indicate standard deviations. Letters (a, b, c, d, e) indicate significant differences between different treatments $(\mathrm{p}<0.05$, Tukey's test).

Similar results were found for wheat $\mathrm{N}$ content (Figure 2B, Table A1). With MWC, the shoot $\mathrm{N}$ content was doubled ( $p<0.001)$ compared to those of W and MW. Earthworms led to a significant increase in shoot and root $\mathrm{N}$ contents $(\mathrm{p}<0.001)$. No significant change $(\mathrm{p}>0.05)$ was found for root and shoot $\mathrm{N}$ contents in MW compared to the $\mathrm{N}$ contents of $\mathrm{W}$. A significant effect of the two types of earthworms was observed for shoot $\mathrm{N}$ content in $\mathrm{W}$ and $\mathrm{MW}$, with a greater increase in pure stands of wheat. BNF contributed to $90.3 \pm 6.5 \%$ of clover $\mathrm{N}$ content.

\subsection{Effect of Clover and Earthworms on Plant Competition}

The RII values calculated for DW were positive and significantly different from $0(\mathrm{p}<0.001)$, indicating that the competition between plant species decreased when the clover was intercropped with the wheat. This positive effect increased significantly in the presence of earthworms (Figure 3A, Table A2). For N acquisition, positive effects of the presence of clover and earthworms were observed for wheat shoots, and earthworm presence strongly increased the RII for the roots (Figure 3B, Table A2). For MW, earthworms also reduced the competition between wheat plants for biomass production and $\mathrm{N}$ acquisition, showing an additional effect of the two functional groups of earthworms. 


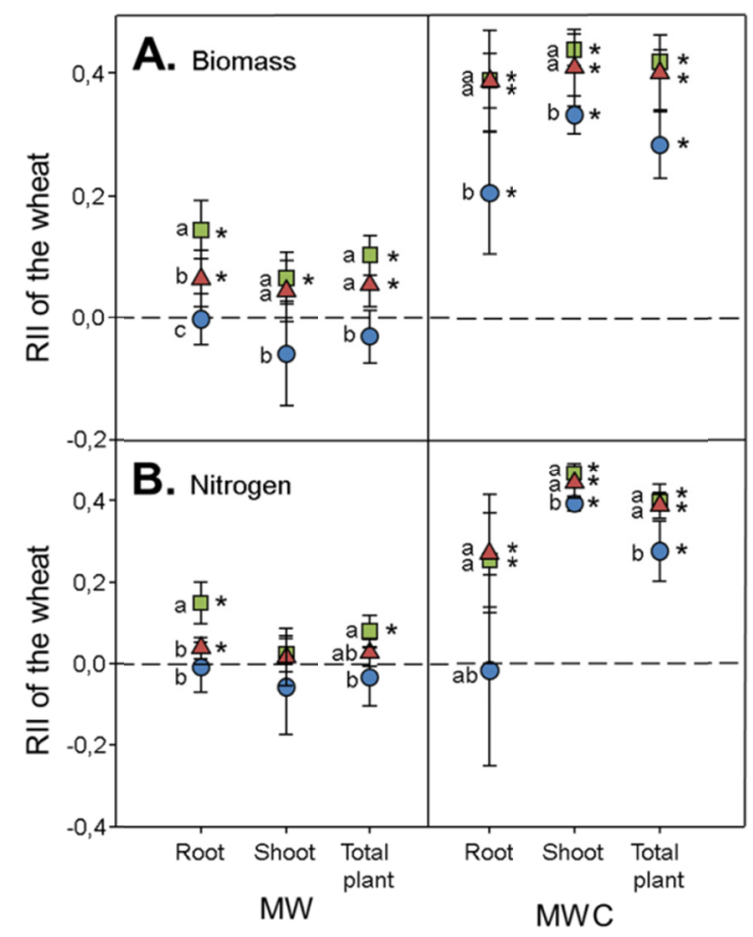

Figure 3. Effect of plant composition and earthworms on interactions between wheat in a mixture of cultivars (MW) and when intercropped (MCW) with clover in relation to biomass production (A) and nitrogen accumulation $(\mathrm{B})$

Note. Blue circles $=$ without earthworms, red triangles $=$ endogeic, green squares $=$ endogeic and anecic. Letters indicate that earthworm treatments are significantly different (Tukey's test). Asterisk (*) symbol indicates that a value is significantly different from 0 ( $\mathrm{p}<0.05$; Student test).

\subsection{Soil Bacterial Biomass and Alpha-Diversity Index}

Soil bacterial biomass decreased in the presence of plants, compared to NP ( $p<0.001$, Figure 4, Table A3). Values were significantly higher for MW and MWC than W. With earthworms, the bacterial biomass increased significantly for NP and W $(\mathrm{p}<0.001)$, with an effect of the two functional groups of earthworms. No effect of earthworms on bacterial biomass was observed for MW and MWC.

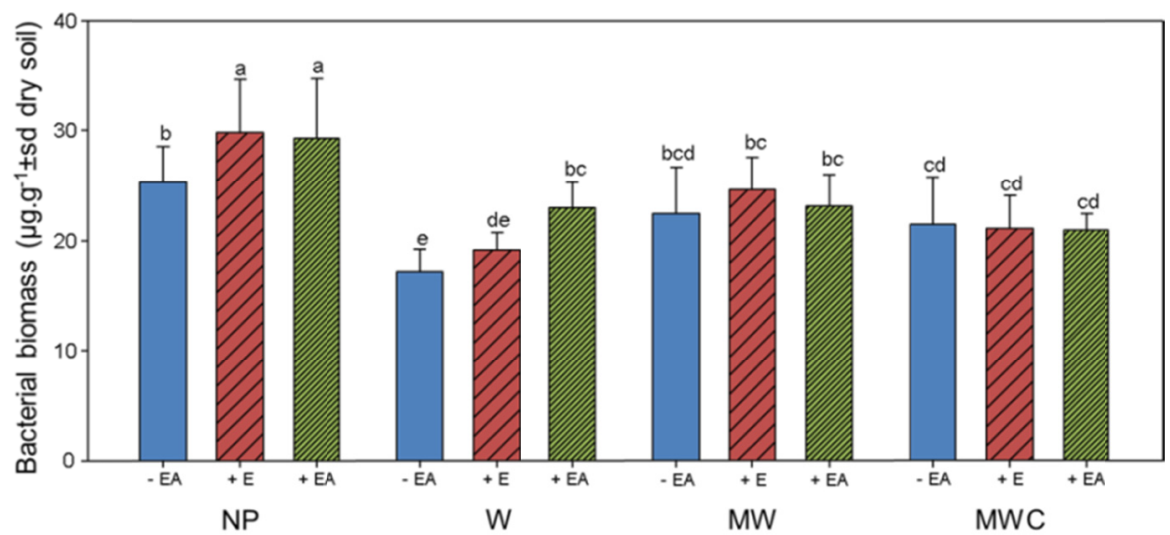

Figure 4. Bacterial biomass in the soil from treatments with different plant cover types and under influence of earthworms

Note. $\mathrm{NP}=$ no plant, $\mathrm{W}=$ single wheat cultivar, $\mathrm{MC}=$ mixture of three wheat cultivars, $\mathrm{MWC}=$ mixture of wheat cultivars intercropped with clover, $-\mathrm{EA}=$ without earthworms, $+\mathrm{E}=$ with endogeic, $+\mathrm{EA}=$ with endogeic and anecic. Values are means of 3 technical replicates and 4 biological replicates. Bars indicate standard deviations. Letters indicate significant differences between different treatments $(\mathrm{p}<0.05$; Tukey test). 


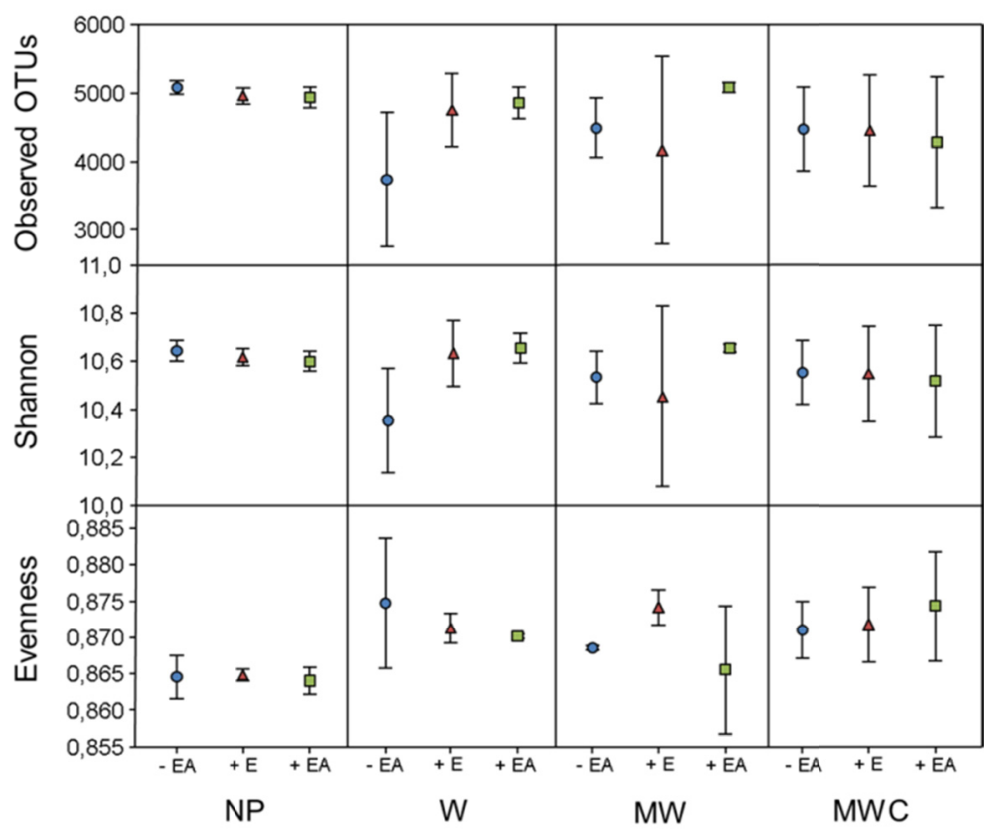

Figure 5. Observed OTUs and Shannon and evenness indices of bacterial communities under the influence of plant cover type and earthworms

Note. $\mathrm{NP}=$ no plants, $\mathrm{W}=$ single wheat cultivar, $\mathrm{MW}=$ mixture of three wheat cultivars, $\mathrm{MWC}=$ mixture of wheat cultivars intercropped with clover, $-\mathrm{EA}=$ without earthworms, $+\mathrm{E}=$ with endogeic, $+\mathrm{EA}=$ with endogeic and anecic). Values are means \pm standard deviations, $\mathrm{n}=4$.

With respect to sequences that were clustered, there were no significant differences between treatments for observed OTUs (from $3738.33 \pm 984.06$ to $5082.25 \pm 95.07$ ), Shannon indice (from $10.35 \pm 0.22$ to $10.65 \pm 0.02$ ) and evenness (from $0.864 \pm 0.002$ to $0.875 \pm 0.009$ ) (Figure 5, Table A3).

\section{Discussion}

\subsection{Combined Effects}

Wheat benefited from the presence of earthworms, with a combined effect of anecic and endogeic earthworms. An increase in grass shoot biomass and $\mathrm{N}$ content in the presence of both A. caliginosa and L. terrestris was also earlier reported by Partsch et al. (2006). According to their different ecological traits, A. caliginosa increases $\mathrm{N}$ mineralization from SOM, whereas $L$. terrestris increases $\mathrm{N}$ mineralization from crop residues and thus can have positive effects on global N mineralization (Villenave et al., 1999; Whalen et al., 2000; Cortez \& Hameed, 2001). Consequently, wheat $\mathrm{N}$ uptake should be enhanced by an overall higher level of soil mineral $\mathrm{N}$ availability due to physical (cast production and burrows) and physiological activities of earthworms, which strongly interact with soil properties and microbial populations (Brown et al., 2004; Postma-Blaauw et al., 2006). We cannot reject a possible stimulation of nutrient release via decomposition of the daily input of grass by the anecic species. A positive effect of the combined ecological traits of anecic and endogeic groups thus has to be mitigated for the wheat treatments, whereas no effect was observed in the wheat-clover treatment, suggesting no significant impact of grass input.

As expected, the addition of clover contributed to higher biomass and $\mathrm{N}$ content of the wheat (Corre-Hellou et al., 2006). At the end of the experiment, $90 \%$ of the clover $\mathrm{N}$ was due to $\mathrm{N}_{2}$ fixation, which confirmed the establishment of niche complementarity for the use of $\mathrm{N}$ sources, and possible indirect positive interactions for the intercropped wheat via rhizosphere modifications (RII > 0; Figure 3). In the present study, earthworms, at least endogeic species, also benefited wheat performance by contributing to the reduction of competition between plants and increasing facilitation processes, in addition to the positive effect of clover. Our results are in agreement with those of Kreuzer et al. (2004) and Coulis et al. (2014) who reported a higher N acquisition by plants in the presence of endogeic earthworms. As shown by Eck et al. (2015), A. caliginosa is known to cause an apparent priming effect in old native SOM as a result of mucus that it produces, which provides a significant input of fresh organic matter (Bityutskii et al., 2012a). This phenomenon consists of modifications of SOM 
decomposition rates (mostly an acceleration) triggered by the input of energy sources that are easily decomposed by the soil microbial biomass (Blagodatskaya \& Kuzyakov, 2008). Accordingly, earthworm activities improved the environmental growth conditions, directly contributing to the availability of nutrients, such as nitrogen, in the rhizosphere. Milcu et al. (2008) found that legumes and earthworms benefited from each other's presence via mutualistic interactions. The performances of earthworms increased due to N-rich legume rhizodeposits (Milcu et al. 2006; Eck et al., 2015), and higher degrees of decomposition and increased soil nutrient availability due to the presence of earthworms benefits legumes. We suggest that both the rhizodeposition of labile $\mathrm{C}$ substrates by clover and mucus secretion by earthworms provided large amounts of nutrients for microbial communities, leading to acceleration of SOM mineralisation in the rhizosphere of wheat-clover intercropped lands. This probably indicates that wheat benefited from the synergistic effects of legumes and earthworms in the present study.

\subsection{Effects of Plants and Earthworms on Bacterial Communities}

Previous studies linked increases in microbial biomass with increases in plant functional diversity or composition, with a key role played by the presence of legumes (Eisenhauer et al., 2010). In the present study, bacterial biomass was increased in the wheat-clover intercrop but also in the mixture of wheat cultivars. The diversification of rhizodeposits by introducing a legume or by increasing genotypic variation could explain the stimulation of microbial communities that use root exudates as their main $\mathrm{C}$ source. Indeed, C-enriched exudates drove interactions between plants and microorganisms and, microbial biomass has been shown to vary with a greater diversity of root exudates due to plant diversity (Eisenhauer et al., 2010; Steinauer et al., 2016). Moreover, Milcu et al. (2006) suggested that the function of soil microorganisms is more affected by the quality than the quantity of rhizodeposits and is affected by the quantity of available resources. When resources become limiting, microbes can compete with plants, especially for organic N (Bardgett et al., 2003), which may explain the lower bacterial biomass observed in the single-wheat cultivar treatment. As previously indicated, earthworm activities modify the rhizosphere environment, increasing resource availability for soil microorganisms and positively affecting their biomass. However, earthworms also compete with microorganisms for limited resources (Milcu et al., 2006), and microbial biomass can be impacted by microorganism consumption by earthworms (Devliegher \& Verstraete, 1997; Chapuis-Lardy et al., 2010). In particular, endogeic earthworms use large amounts of $C$, which increases $C$ limitations for microorganisms (Tiunov \& Scheu, 2004) and may contribute to the low responsiveness of microbial biomass in our plant treatments. Higher bacterial biomass in treatments without plants tended to confirm an increase in competition between microbes and other organisms (plants and earthworms) when they were present in the mesocosms. In our study the lack of effect on the bacterial community indices may be due to the simplification of the biological system to the short duration of the experiment. In the field, endogeic earthworms can shape the composition of bacterial communities and biological interactions within the soil foodweb can impact the dispersion of microbes, which is more limited among enclosed mesocosms. Moreover, referring to the long-term Jena Experiment, Eisenhauer et al. (2010) highlighted the significant effects of plant functional group richness on soil microorganisms only two to four years after community establishment. This supports a time-lag in the response of microbial community structure to changes in functional plant community composition. In our study, the short-term influence of root exudates and earthworm activities might have altered the density and activity of the microorganisms but not the diversity.

\section{Conclusions}

Complementarity for nutrient use between our different wheat cultivars was not strong enough to have an effect on plant performance. However, with clover, complementarity benefited wheat biomass and $\mathrm{N}$ accumulation, which were strengthened by earthworm facilitation. Endogeic earthworms altered interactions between plants and highly reduced below-ground competition, likely due to higher mineralization rates and increased $\mathrm{N}$ availability. In wheat-clover mesocosms, despite the higher level of complementarity for $\mathrm{N}$ sources between plants compared to that present in wheat mesocosms, the addition of a second functional group of worms (anecic) had no supplementary effect on wheat performance. This suggests that in our experimental conditions (poor soil, limited volume), resources were too limited to allow for more benefits to the wheat from biotic interactions and/or that the two groups of earthworms have more expressed functional redundancies than potential complementarities. Wheat performance was increased in the presence of a less competitive legume and improved by the presence of earthworms, suggesting that the plant functional group, such as legumes, and earthworm communities function synergistically to improve wheat yields. An improved mechanistic understanding of the role of this coupled effect in intercropping systems will be beneficial for sustainable agricultural systems less reliant on fertilizers. 


\section{Acknowledgements}

Research was supported by the Regions Pays-de-la-Loire and Bretagne (France) as part of the project SAFARI. We thank the technical staff of LEVA and the staff of the LUBEM for their technical assistance. We are most grateful to the PLATIN' (Plateau d'Isotopie de Normandie) core facility for all element and isotope analyses performed in this study.

\section{References}

Armas, C., Ordiales, R., \& Pugnaire, F. I. (2004). Measuring plant interactions: A new comparative index. Ecology, 85, 2682-2686. https://doi.org/10.1890/03-0650

Balesdent, J., Derrien, D., Fontaine, S., Kirman, S., Klumpp, K., Loiseau, P., ... Personeni, E. (2011). Contribution de la rhizodéposition aux matières organiques du sol, quelques implications pour la modélisation de la dynamique du carbone. Etude et Gestion des Sols, 18, 201-216.

Bardgett, R. D., Streeter, T. C., \& Bol, R. (2003). Soil microbes compete effectively with plants for organic-nitrogen inputs to temperate grasslands. Ecology, 84, 1277-1287. https://doi.org/10.1890/0012-9658 (2003)084[1277:SMCEWP]2.0.CO;2

Bédoussac, L., Journet, E.-P., Hauggaard-Nielsen, H., Naudin, C., Corre-Hellou, G., Jensen, E. S., ... Justes, E. (2015). Ecological principles underlying the increase of productivity achieved by cereal-grain legume intercrops in organic farming: A review. Agronomy for Sustainable Development, 1-25. https://doi.org/ 10.1007/s13593-014-0277-7

Bernard, L., Chapuis-Lardy, L., Razafimbelo, T., Razafindrakoto, M., Pablo, A.-L., Legname, E., ... Brauman, A. (2012). Endogeic earthworms shape bacterial functional communities and affect organic matter mineralization in a tropical soil. The ISME Journal, 6, 213-222. https://doi.org/10.1038/ismej.2011.87

Bityutskii, N., Maiorov, E., \& Orlova, N. (2012a). The priming effects induced by earthworm mucus on mineralization and humification of plant residues. European Journal of Soil Biology, 50, 1-6. https://doi.org/ 10.1016/j.ejsobi.2011.11.008

Bityutskii, N. P., Kaidun, P. I., \& Yakkonen, K. L. (2012b). The earthworm (Aporrectodea caliginosa) primes the release of mobile and available micronutrients in soil. Pedobiologia, 55, 93-99. https://doi.org/10.1016/ j.pedobi.2011.11.003

Blagodatskaya, E., \& Kuzyakov, Y. (2008). Mechanisms of real and apparent priming effects and their dependence on soil microbial biomass and community structure: Critical review. Biology and Fertility of Soils, 45, 115-131. https://doi.org/10.1007/s00374-008-0334-y

Bobille, H., Limami, A. M., Robins, R. J., Cukier, C., Le Floch, G., \& Fustec, J. (2016). Evolution of the amino acid fingerprint in the unsterilized rhizosphere of a legume in relation to plant maturity. Soil Biology \& Biochemistry, 101, 226-236. https://doi.org/10.1016/j.soilbio.2016.07.022

Brolsma, K. M., Arie Vonk, J., Mommer, L., Van Ruijven, J., Ellis Hoffland, E., \& De Goede R. G. M. (2017). Microbial catabolic diversity in and beyond the rhizosphere of plant species and plant genotypes. Pedobiologia, 61, 43-49. https://doi.org/10.1016/j.pedobi.2017.01.006

Brooker, R. W., Karley, A. J., Newton, A. C., Pakeman, R. J., \& Schöb, C. (2016). Facilitation and sustainable agriculture: A mechanistic approach to reconciling crop production and conservation. Functional Ecology, 30, 98-107. https://doi.org/10.1111/1365-2435.12496

Brown, G. G., Edwards, C. A., \& Brussaard, L. (2004). How earthworms affect plant growth: Burrowing into the mechanisms. In C. A. Edwards (Ed.), Earthworm Ecology. CRC Press.

Brown, S. P., Veach, A. M., Rigdon-Huss, A. R., Grond, K., Lickteig, S. K., Lothamer, K., ... Jumpponen, A. (2015). Scraping the bottom of the barrel: are rare high throughput sequences artifacts? Fungal Ecology, 13, 221-225. https://doi.org/10.1016/j.funeco.2014.08.006

Caporaso, J. G., Kuczynski, J., Stombaugh, J., Bittinger, K., Bushman, F. D., Costello, E. K., ... Gordon, J. I. (2010). QIIME allows analysis of high-throughput community sequencing data. Nature Methods, 7, 335-336. https://doi.org/10.1038/nmeth.f.303

Chapuis-Lardy, L., Brauman, A., Bernard, L., Pablo, A. L., Toucet, J., Mano, M. J., ... Blanchart, E. (2010). Effect of the endogeic earthworm Pontoscolex corethrurus on the microbial structure and activity related to $\mathrm{CO}_{2}$ and $\mathrm{N}_{2} \mathrm{O}$ fluxes from a tropical soil (Madagascar). Applied Soil Ecology, 45, 201-208. https://doi.org/ 10.1016/j.apsoil.2010.04.006 
Corre-Hellou, G., \& Crozat, Y. (2005). Assessment of root system dynamics of species grown in mixtures under field conditions using herbicide injection and ${ }^{15} \mathrm{~N}$ natural abundance methods: A case study with pea, barley and mustard. Plant and Soil, 276, 177-192. https://doi.org/10.1007/s11104-005-4275-z

Corre-Hellou, G., Fustec, J., \& Crozat, Y. (2006). Interspecific competition for soil $\mathrm{N}$ and its interaction with $\mathrm{N}_{2}$ fixation, leaf expansion and crop growth in pea-barley intercrops. Plant and Soil, 282, 195-208. https://doi.org/10.1007/s11104-005-5777-4

Cortez, J., \& Hameed, R. (2001). Simultaneous effects of plants and earthworms on mineralisation of ${ }_{15} \mathrm{~N}$-labelled organic compounds adsorbed onto soil size fractions. Biology and Fertility of Soils, 33, 218-225. https://doi.org/10.1007/s003740000311

Coulis, M., Bernard, L., Gérard, F., Hinsinger, P., Plassard, C., Villeneuve, M., \& Blanchart, E. (2014). Endogeic earthworms modify soil phosphorus, plant growth and interactions in a legume-cereal intercrop. Plant and Soil, 379, 149-160. https://doi.org/10.1007/s11104-014-2046-4

Curry, J. P., \& Schmidt, O. (2007). The feeding ecology of earthworms-A review. Pedobiologia, 50, 463-477. https://doi.org/10.1016/j.pedobi.2006.09.001

Dennis, P. G., Miller, A. J., \& Hirsch, P. R. (2010). Are root exudates more important than other sources of rhizodeposits in structuring rhizosphere bacterial communities? FEMS Microbiology Ecology, 72, 313-327. https://doi.org/10.1111/j.1574-6941.2010.00860.x

Devliegher, W., \& Verstraete, W. (1997). The effect of Lumbricus terrestris on soil in relation to plant growth: Effects of nutrient-enrichment processes (NEP) and gut-associated processes (GAP). Soil Biology \& Biochemistry, 29, 341-346. https://doi.org/10.1016/S0038-0717(96)00096-X

Dijkstra, F. A., Cheng, W., \& Johnson, D. W. (2006). Plant biomass influences rhizosphere priming effects on soil organic matter decomposition in two differently managed soils. Soil Biology \& Biochemistry, 38, 2519-2526. https://doi.org/10.1016/j.soilbio.2006.02.020

Duchene, O., Vian, J. F., \& Celette, F. (2017). Intercropping with and the importance of soil microorganisms: A review. Agriculture, Ecosystems and Environment, 240, 148-161. https://doi.org/10.1016/j.agee.2017.02.019

Eck, T., Potthoff, M., Dyckmans, J., Wichern, F., \& Joergensen, R. G. (2015). Priming effects of Aporrectodea caliginosa on young rhizodeposits and old soil organic matter following wheat straw addition. European Journal of Soil Biology, 70, 38-45. https://doi.org/10.1016/j.ejsobi.2015.07.002

Edgar, R. C. (2010). Search and clustering orders of magnitude faster than BLAST. Bioinformatics, 26, 2460-2461. https://doi.org/10.1093/bioinformatics/btq461

Edgar, R. C., Haas, B. J., Clemente, J. C., Quince, C., \& Knight, R. (2011). UCHIME improves sensitivity and speed of chimera detection. Bioinformatics, 27, 2194-2200. https://doi.org/10.1093/bioinformatics/btr381

Eisenhauer, N. (2012). Aboveground-belowground interactions as a source of complementarity effects in biodiversity experiments. Plant and Soil, 351, 1-22. https://doi.org/10.1007/s11104-011-1027-0

Eisenhauer, N., Beßler, H., Engels, C., Gleixner, G., Habekost, M., Milcu, A., ... Steinbeiss, S. (2010). Plant diversity effects on soil microorganisms support the singular hypothesis. Ecology, 91, 485-496. https://doi.org/10.1890/08-2338.1

Eisenhauer, N., \& Scheu, S. (2008). Earthworms as drivers of the competition between grasses and legumes. Soil Biology \& Biochemistry, 40, 2650-2659. https://doi.org/10.1016/j.soilbio.2008.07.010

Fang, Y., Xu, B., Liu, L., Gu, Y., Liu, Q., Turner, N. C., \& Li, F. M. (2014). Does a mixture of old and modern winter wheat cultivars increase yield and water use efficiency in water-limited environments? Field Crops Research, 156, 12-21. https://doi.org/10.1016/j.fcr.2013.10.013

Fustec, J., Lesuffleur, F., Mahieu, S., \& Cliquet, J.-B. (2010). Nitrogen rhizodeposition of legumes. A review. Agronomy for Sustainable Development, 30, 57-66. https://doi.org/10.1051/agro/2009003

Gaba, S., Lescourret, F., Boudsocq, S., Enjalbert, J., Hinsinger, P., Journet, E.-P., ... Malézieux, E. (2015). Multiple cropping systems as drivers for providing multiple ecosystem services: from concepts to design. Agronomy for Sustainable Development, 35, 607-623. https://doi.org/10.1007/s13593-014-0272-z

Galloway, J. N., Aber, J. D., Erisman, J. W., Seitzinger, S. P., Howarth, R. W., Cowling, E. B., \& Cosby, B. J. (2003). The nitrogen cascade. BioScience, 53, 341-356. https://doi.org/10.1641/0006-3568(2003)053 [0341:TNC]2.0.CO;2 
Gómez-Brandón, M., Lazcano, C., Lores, M., \& Domínguez, J. (2010). Detritivorous earthworms modify microbial community structure and accelerate plant residue decomposition. Applied Soil Ecology, 44, 237-244. https://doi.org/10.1016/j.apsoil.2009.12.010

Haas, B. J., Gevers, D., Earl, A. M., Feldgarden, M., Ward, D. V., Giannoukos, G., ... Sodergren, E. (2011). Chimeric 16S rRNA sequence formation and detection in Sanger and 454-pyrosequenced PCR amplicons. Genome Research, 21, 494-504. https://doi.org/10.1101/gr.112730.110

Hauggaard-Nielsen, H., Gooding, M., Ambus, P., Corre-Hellou, G., Crozat, Y., Dahlmann, C., ... Jensen, E. S. (2009). Pea-barley intercropping for efficient symbiotic $\mathrm{N}_{2}$-fixation, soil $\mathrm{N}$ acquisition and use of other nutrients in European organic cropping systems. Field Crops Research, 113, 64-71. https://doi.org/10.1016 /j.fcr.2009.04.009

Kowalchuk, G. A., Buma, D. S., de Boer, W., Klinkhamer, P. G., \& van Veen, J. A. (2002). Effects of above-ground plant species composition and diversity on the diversity of soil-borne microorganisms. Antonie Van Leeuwenhoek, 81, 509-520. https://doi.org/10.1023/A:1020565523615

Kreuzer, K., Bonkowski, M., Langel, R., \& Scheu, S. (2004). Decomposer animals (Lumbricidae, Collembola) and organic matter distribution affect the performance of Lolium perenne (Poaceae) and Trifolium repens (Fabaceae). Soil Biology \& Biochemistry, 36, 2005-2011. https://doi.org/10.1016/j.soilbio.2004.05.019

Kuzyakov, Y., \& Xu, X. (2013). Competition between roots and microorganisms for nitrogen: Mechanisms and ecological relevance. New Phytologist, 198, 656-669. https://doi.org/10.1111/nph.12235

Laossi, K.-R., Noguera, D. C., Bartolomé-Lasa, A., Mathieu, J., Blouin, M., \& Barot, S. (2009). Effects of an endogeic and an anecic earthworm on the competition between four annual plants and their relative fecundity. Soil Biology \& Biochemistry, 41, 1668-1673. https://doi.org/10.1016/j.soilbio.2009.05.009

Laughlin, D. C., Hart, S. C., Kaye, J. P., \& Moore, M. M. (2010). Evidence for indirect effects of plant diversity and composition on net nitrification. Plant Soil, 330, 435-445. https://doi.org/10.1007/s11104-009-0217-5

Lavelle, P., \& Spain, A. (2001). Soil Ecology. Springer Science \& Business Media. https://doi.org/10.1007/978 -94-017- 5279-4

Lee, K. E. (1985). Earthworms: Their ecology and relationships with soils and land use. Academic Press Inc.

Milcu, A., Partsch, S., Langel, R., \& Scheu, S. (2006). The response of decomposers (earthworms, springtails and microorganisms) to variations in species and functional group diversity of plants. Oikos, 112, 513-524. https://doi.org/10.1111/j.0030-1299.2006.14292.x

Milcu, A., Partsch, S., Scherber, C., Weisser, W. W., \& Scheu, S. (2008). Earthworms and legumes control litter decomposition in a plant diversity gradient. Ecology, 89, 1872-1882. https://doi.org/10.1890/07-1377.1

Mudrák, O., \& Frouz, J. (2018). Earthworms increase plant biomass more in soil with no earthworm legacy than in earthworm - mediated soil, and favour late successional species in competition. Functional Ecology, 32, 3. https://doi.org/10.1111/1365-2435.12999

Nadkarni, M. A., Martin, F. E., Jacques, N. A., \& Hunter, N. (2002). Determination of bacterial load by real-time PCR using a broad-range (universal) probe and primers set. Microbiology, 148, 257-266. https://doi.org/ 10.1099/00221287-148-1-257

Neugschwandtner, R. W., \& Kaul, H.-P. (2015). Nitrogen uptake, use and utilization efficiency by oat-pea intercrops. Field Crops Research, 179, 113-119. https://doi.org/10.1016/j.fcr.2015.04.018

Oliver, A. K., Brown, S. P., Callaham, M. A., \& Jumpponen, A. (2015). Polymerase matters: Non-proofreading enzymes inflate fungal community richness estimates by up to 15\%. Fungal Ecology, 15, 86-89. https://doi.org/10.1016/j.funeco.2015.03.003

Partsch, S., Milcu, A., \& Scheu, S. (2006). Decomposers (Lumbricidae, Collembola) affect plant performance in model grasslands of different diversity. Ecology, 87, 2548-2558. https://doi.org/10.1890/0012-9658 (2006)87[2548:DLCAPP]2.0.CO;2

Paterson, E., Thornton, B., Midwood, A. J., \& Sim, A. (2005). Defoliation alters the relative contributions of recent and non-recent assimilate to root exudation from Festuca rubra. Plant, Cell \& Environment, 28, 1525-1533. https://doi.org/10.1111/j.1365-3040.2005.01389.x 
Pelzer, E., Bazot, M., Makowski, D., Corre-Hellou, G., Naudin, C., Al Rifaï, M., ... Boucheny, P. (2012). Pea-wheat intercrops in low-input conditions combine high economic performances and low environmental impacts. European Journal of Agronomy, 40, 39-53. https://doi.org/10.1016/j.eja.2012.01.010

Ponge, J. F., Pérès, G., Guernion, M., Ruiz-Camacho N., Cortet, J., Pernind, C., ... Cluzeau, D. (2013). The impact of agricultural practices on soil biota: A regional study. Soil Biology and Biochemistry, 67, $271-284$. https://doi.org/10.1016/j.soilbio.2013.08.026

Postma-Blaauw, M. B., Bloem, J., Faber, J. H., van Groenigen, J. W., de Goede, R. G. M., \& Brussaard, L. (2006). Earthworm species composition affects the soil bacterial community and net nitrogen mineralization. Pedobiologia, 50, 243-256. https://doi.org/10.1016/j.pedobi.2006.02.001

Puga-Freitas, R., Barot, S., Taconnat, L., Renou, J.-P., \& Blouin, M. (2012). Signal molecules mediate the impact of the earthworm Aporrectodea caliginosa on growth, development and defence of the plant Arabidopsis thaliana. PLoS One, 7(12) e4950. https://doi.org/10.1371/journal.pone.0049504

R Core Team. (2014). R: A Language and Environment for Statistical Computing. R Foundation for Statistical Computing, Vienna. http://www.R-Project.org/.

Sarandon S. J., \& Sarandon, R. (1995). Mixture of Cultivars: Pilot Field Trial of an Ecological Alternative to Improve Production or Quality of Wheat (Triticum aestivum). Journal of Applied Ecology, 32, $288-294$. https://doi.org/10.2307/2405096

Scheu, S. (2003). Effects of earthworms on plant growth: Patterns and perspectives: The 7th international symposium on earthworm ecology, Cardiff, Wales, 2002. Pedobiologia, 47, 846-856. https://doi.org/ 10.1016/S0031-4056(04)70279-6

Shearer, G., \& Kohl, D. H. (1986). N2-fixation in field settings: Estimations based on natural ${ }^{15} \mathrm{~N}$ abundance. Functional Plant Biology, 13, 699-756. https://doi.org/10.1071/PP9860699

Steinauer, K., Chatzinotas, A., \& Eisenhauer, N. (2016). Root exudate cocktails: The link between plant diversity and soil microorganisms? Ecology and Evolution, 6(20), 7387-7396. https://doi.org/10.1002/ece3.2454

Taschen, E., Amenc, L., Tournier, E., Deleporte, P., Malagoli, P., Fustec, J., ... Bernard, L. (2017). Cereal-legume intercropping modifies the dynamics of the active rhizospheric bacterial community. Rhizosphere, 3(Part 1), 191-195. https://doi.org/10.1016/j.rhisph.2017.04.011

Tiunov, A. V., \& Scheu, S. (2004). Carbon availability controls the growth of detritivores (Lumbricidae) and their effect on nitrogen mineralization. Oecologia, 138, 83-90. https://doi.org/10.1007/s00442-003-1391-4

van Groenigen, J. W., Lubbers, I. M., Brown, G. G., De Deyn, G. B., \& van Groenigen, K. J. (2014). Earthworms increase plant production: A meta-analysis. Scientific Reports, 4, 6365. https://doi.org/10.1038/ srep06365

Villenave, C., Charpentier, F., Lavelle, P., Feller, C., Brussaard, L., Pashanasi, B., .. Patron, J. C. (1999). Effects of earthworms on soil organic matter and nutrient dynamics following earthworm inoculation in field experimental situations. In P. Lavelle, L. Brussaard, \& P. Hendrix (Eds.), Earthworm management in tropical agroecosystems (pp. 173-197). Wallingford.

Whalen, J. K., Parmelee, R. W., \& Subler, S. (2000). Quantification of nitrogen excretion rates for three lumbricid earthworms using ${ }^{15}$ N. Biology and Fertility of Soils, 32, 347-352. https://oi.org/10.1007/ s003740000259

Willey, R. W. (1979). Intercropping-its importance and research needs: Part 1. Competition and yield advantages. Field Crop Abstracts, 32, 1-10.

Wurst, S., Langel, R., \& Scheu, S. (2005). Do endogeic earthworms change plant competition? A microcosm study. Plant and Soil, 271, 123-130. https://doi.org/10.1007/s11104-004-2201-4

Zancarini, A., Mougel, C., Voisin, A.-S., Prudent, M., Salon, C., \& Munier-Jolain, N. (2012). Soil nitrogen availability and plant genotype modify the nutrition strategies of $M$. truncatula and the associated rhizosphere microbial communities. PLoS One, 7, e47096. https://doi.org/10.1371/journal.pone.0047096

Zhu, B., \& Cheng, W. (2012). Nodulated soybean enhances rhizosphere priming effects on soil organic matter decomposition more than non-nodulated soybean. Soil Biology \& Biochemistry, 51, 56-65. https://doi.org/ 10.1016/j.soilbio.2012.04.016 


\section{Appendix A}

\section{Results of ANOVAs}

Table A1. Results of ANOVA to test for the effects of plant composition and earthworms on the root and shoot biomass and $\mathrm{N}$ content

\begin{tabular}{|c|c|c|c|c|c|c|c|c|c|c|c|c|}
\hline \multirow{2}{*}{ Source of variance } & \multicolumn{3}{|c|}{ Root biomass } & \multicolumn{3}{|c|}{ Shoot biomass } & \multicolumn{3}{|c|}{ Root $\mathrm{N}$ content } & \multicolumn{3}{|c|}{ Shoot $\mathrm{N}$ content } \\
\hline & df & $F$-value & p-value & df & F-value & p-value & $\mathrm{df}$ & $F$-value & p-value & df & $F$-value & $p$-value \\
\hline \multicolumn{13}{|l|}{ Treatments } \\
\hline Plant (P) & 2 & 95.00 & $<0.001$ & 2 & 567.26 & $<0.001$ & 2 & 6.21 & 0.005 & 2 & 510.36 & $<0.001$ \\
\hline Worms (E) & 2 & 26.15 & $<0.001$ & 2 & 44.44 & $<0.001$ & 2 & 12.17 & $<0.001$ & 2 & 27.04 & $<0.001$ \\
\hline $\mathrm{P} \times \mathrm{E}$ & 4 & 1.79 & 0.154 & 4 & 0.61 & 0.657 & 4 & 2.47 & 0.064 & 4 & 1.59 & 0.199 \\
\hline
\end{tabular}

Table A2. Results of ANOVA to test for the effects of earthworms on the RII for the wheat root, shoot and total biomass and $\mathrm{N}$ accumulation in the cultivar mixture (MW) and intercrop with clover (MWC)

\begin{tabular}{|c|c|c|c|c|c|c|c|c|c|}
\hline \multirow{3}{*}{ Source of variance } & \multicolumn{9}{|c|}{ RII for the wheat } \\
\hline & \multicolumn{3}{|c|}{ Root } & \multicolumn{3}{|c|}{ Shoot } & \multicolumn{3}{|c|}{ Total } \\
\hline & df & $F$-value & p-value & $\mathrm{df}$ & $F$-value & p-value & df & $F$-value & $p$-value \\
\hline \multicolumn{10}{|l|}{ Biomass production } \\
\hline MW & 2 & 13.4 & $<0.001$ & 2 & 5.61 & 0.019 & 2 & 16.38 & $<0.001$ \\
\hline MWC & 2 & 8.84 & 0.004 & 2 & 7.95 & $<0.001$ & 2 & 11.68 & 0.001 \\
\hline \multicolumn{10}{|l|}{ N accumulation } \\
\hline MW & 2 & 13.78 & $<0.001$ & 2 & 1.47 & 0.268 & 2 & 6.20 & 0.014 \\
\hline MWC & 2 & 4.32 & 0.038 & 2 & 9.95 & 0.002 & 2 & 8.28 & 0.005 \\
\hline
\end{tabular}

Table A3. Results of ANOVA to test for the effects of plant composition and earthworms on the soil bacterial biomass and community indices

\begin{tabular}{|c|c|c|c|c|c|c|c|c|c|c|c|c|}
\hline \multirow{2}{*}{ Source of variance } & \multicolumn{3}{|c|}{ Bacterial biomass } & \multicolumn{3}{|c|}{ Observed OTUs } & \multicolumn{3}{|c|}{ Shannon } & \multicolumn{3}{|c|}{ Evenness } \\
\hline & $\mathrm{df}$ & f F-value & p-value & $\mathrm{df}$ & f F-value & p-value & $\mathrm{df}$ & f F-value & p-value & $\overline{\mathrm{df}}$ & $F$-value & p-value \\
\hline \multicolumn{13}{|l|}{ Treatments } \\
\hline Plant (P) & 2 & 34.46 & $<0.001$ & 2 & 1.36 & 0.276 & 2 & 0.07 & 0.931 & 2 & 1.45 & 0.256 \\
\hline Worms (E) & 2 & 9.76 & $<0.001$ & 2 & 0.35 & 0.709 & 2 & 1.50 & 0.245 & 2 & 0.47 & 0.628 \\
\hline $\mathrm{P} \times \mathrm{E}$ & 4 & 2.76 & 0.014 & 4 & 1.81 & 0.163 & 4 & 1.96 & 0.137 & 4 & 1.74 & 0.177 \\
\hline
\end{tabular}

\section{Copyrights}

Copyright for this article is retained by the author(s), with first publication rights granted to the journal.

This is an open-access article distributed under the terms and conditions of the Creative Commons Attribution license (http://creativecommons.org/licenses/by/4.0/). 